\title{
From the Yukon to Hell: The War Rhymes of Robert Service
}

\author{
Edward J. Cowan \\ University of Glasgow
}

Abstract: The Scottish poet Robert Service has often been described as a mere rhymester, noted, if at all, for his Yukon ballads. This article argues that he was a highly talented folk poet whose best work was written as a result of his experiences in the First World War. His ideas of social Darwinism, so obvious in the brilliant Yukon poems, were transferred to the horror of warfare after he quit the Dawson for good in 1912. He first worked as a war correspondent sending reports, at least one of which was duplicated in the Dawson Daily News, to the Toronto Star. Images that first appeared in his journalism were re-used for his poems. He then joined the American Ambulance Unit to gain some further knowledge of the action, encounters that inspired his Rhymes of A Red Cross Man, a bestseller that represents some of his very finest work. He was highly successful in capturing the thoughts, fears, and heroism of soldiers who confronted at first hand the bloody filth and fatuity of trench warfare. He conjured images of death and dying that have now almost become clichés. He was anti-war but he had endless sympathy for the humble men who found themselves with commissions to kill or be killed. It is noteworthy that he did not forget the plight of the women who were condemned to remain in ignorance of their loved ones or, worse, to the prospect of lengthy widowhoods. It is time to recognize his achievement. This article is part of a special collection of papers originally presented at a conference on "The North and the First World War," held May 2016 in Whitehorse, Yukon.

The Northern Review 44 (2017): 243-265 
One of my professional interests has been in those Scots, mostly but not exclusively in the fur trade, who introduced the Arctic and Far Northwest region to the rest of the world, complementing the greater achievements of Russians down to the nineteenth century. My fellow countrymen who, for good or ill, made a contribution included Alexander Mackenzie; George Simpson of the Hudson's Bay Company; and Robert Campbell, the first Euro-Canadian to cross from the Mackenzie to the Yukon Riveraccording to one American writer, "the rugged Scottish hills of his father's sheep farm had strengthened his tall broad-shouldered physique for the deprivation of the North American frontier"1; Scottish exceptionalism transposed to the Yukon! The Yukon has a bit of catching up to do. The Scots have been talking up their exceptionalism for some 2,000 years!

A convinced Calvinist, Campbell carried the Bible everywhere with him. ${ }^{2}$ Others were John Bell (erroneously described as an Englishman), who established a trading post at Fort Mcpherson (Tetl'it Zheh); Alexander Kennedy Isbister, a champion of Indigenous peoples' interests; missionary Robert Mcdonald; and Alexander Hunter Murray, who established a trading post at Fort Yukon (Gwichyaa Zheh) in Alaska, married Anne Campbell, and became a student of Kutchin (Gwich'in) ethnology. ${ }^{3}$ His sketches and paintings were reproduced by John Richardson, from my hometown of Dumfries, in his Arctic Searching Expedition (1851), which described his search for Franklin. Richardson, who had much to say about the Gwich'in, also inspired the remarkable four volume Fauna Boreali-Americana series, the first serious study of northern natural history, writing those on mammals and fish. ${ }^{4}$

The Scots bought heavily into the Anglo-Saxon Empire myth. Indeed, in the late nineteenth century some of our citizens argued that they were actually more Anglo-Saxon than the English. The Scots language did not experience the Great Vowel Shift and so Scots speech was deemed to be closer to original Anglo-Saxon than much contaminated English. One Scot boasted that while there were Anglophones and Francophones, he himself was an Anglo-Saxophone! The idea that some people were somehow programmed to make good soldiers-such as Scots and Yukoners-was invented in order to exploit them. General Wolfe, of Plains of Abraham fame, argued that Highlanders were natural fighters, but most importantly he asserted "it is no great mischief if they fall." Churchill is credited with proclaiming, "We will fight to the last Canadian"! The late Cliff Hanley, author, wit, and writer of Scotland the Brave, used to define a born leader of men as someone who was afraid to go anywhere by himself. I mention 
soldiery because the Yukon, like Scotland, had a proud military tradition that bound both places closely into the British Empire. Around twenty of the Yukon's ninety war dead have Scottish names. ${ }^{5}$ It would be interesting to know, therefore, what the veterans and the relatives of the slain thought of the war poems of Robert William Service, another Scotsman and the subject of this paper. He paid tribute to those who followed the trail of ' 98 in his paean to the Yukon:

These silent, patient, toiling ones (who) were the Conquerors of the Great White Land; the Men of the High North, the Brotherhood of the Arctic Wild. No saga will ever glorify their deeds, no epic make them immortal. Their names will be written in the snows that melt and vanish at the smile of Spring; but in their works will they live, and their indomitable spirit will be as a beacon-light, shining down the dim corridors of Eternity. ${ }^{6}$

Service had a love-hate relationship with the landscape itself. Searching for a lost miner, Athol Meldrum - the hero of The Trail of '98, Service's first novel-drops into a deep dark valley with his friends.

Sometimes the valley was like a gaping mouth, and the lips of it were vivid grey ... Sometimes it was like a grey grave full of silence. And here in this place of shadows, where the lichen strangled the trees, and underfoot the moss hushed the tread, where we spoke in whispers, and mirth seemed a mockery, where every stick and stone seemed eloquent of disenchantment and despair, here in this valley of Dead Things,

their mate was eventually found. ${ }^{7}$ If many writers are seers - as Margaret Atwood once assured me they are, when a group of us were delayed for a few days in Yellowknife en route to the High Arctic-then in this passage Robert Service perhaps may be thought to have anticipated some kind of vision of the Great War, just as later he explicitly did when he visited the prehistoric rows of Stones at Carnac in Brittany.

Like soldiers they stand in rank, extending over the moor. The sky is cowled with cloud, save where a sullen sunset shoots blood-red rays across the plain. Bathed in that sinister light stands my army of stone, and a wind swooping down seems to wail amid its ranks. ${ }^{8}$ 
The Darwinian idea of the survival of the fittest links Service's views of the Yukon and the Great War, but Service was fascinated by the realization that occasionally strong men fail and the weak triumph.

Robert Service, arguably the Yukon's most famous resident, is one of the best known, bestselling, and critically most ignored English language writers of the twentieth century. Born in England, raised in his ancestral Scotland, bard of the Yukon and the Canadian North, he spent the bulk of his life domiciled in Brittany with the consequence that he is curiously unclaimed by any particular country. The creator of Dan McGrew, Sam McGee, and a host of memorable characters, struck gold with the publication of his Songs of a Sourdough in 1907, thus attracting for the remainder of his literary life the damning and dismissive label of popular poet or rhymester. He was also a journalist, autobiographer, and a rather poor novelist as well as an adventurer and inveterate observer of the human predicament. This paper will argue that in at least one collection-Rhymes of a Red Cross Man (1916) - he displayed a profundity and originality that he has hitherto been largely denied. The fact that he was President Ronald Reagan's favourite poet should not be held against him!

Excluded from several anthologies of First World War verse, he has been silently edited out by the world of professional criticism, which is guilty of either invincible ignorance or, more likely, of monumental snobbery, since he has continued to outsell every single poet of the First War and that without the safety net of academic prescription. ${ }^{9}$

Born into a Scottish family in Preston, Lancashire, in 1874, Service arrived in Whitehorse in 1904, departing the Yukon and Canada for Europe in 1912. During that eight-year period in the North he almost singlehandedly created a genuine Canadian myth. His work "deserves attention as one of the earliest attempts in Canadian literary history to mythologize the environment," ${ }^{10}$ such that his depiction of the Yukon remains the sole perception of Canada still held by many people worldwide.

He was a socialist who felt guilty about his investments. He protested that he had no great interest in poetry but that he wanted to write verse that would appeal to people at large: "I was always in love with rhyme ... Rhyming has my ruin been. With less deftness I might have produced real poetry." ${ }^{11}$ He was, in short, a folk-poet-the registrar of the pulse of life, and, in Rhymes of a Red Cross Man, of death. ${ }^{12}$ Indeed, death figures prominently in the entire body of his poetic output; he was quite fascinated by it. 
An inescapable influence was the "idol" of his folks, Robert Burns, Scotland's national bard whose rump had often warmed -"one of our parlour chairs." 13 From an early age he began to file away memorable characters in his personal gallery, a talent that he never lost regardless of where he resided. After leaving school he apprenticed as a bank clerk in Glasgow. During this period, according to himself, he flirted with politics though his interest was qualified: "Socialism would be charming ... if one could eliminate the socialist." He preferred to see himself as a radical with socialist sympathies, a perception that is communicated strongly in the war poems.

The Toronto Globe of 5 August 1914 proclaimed, "War is tragedy, not vaudeville." ${ }^{14}$ Vaudeville was part of young Service's education: "its rumtum, rumtittytum inspired some of my verses and when I played at song-composing it was in the tempo of the old-fashioned music hall." Glasgow in the 1890s was "music hall city." He loved the vulgarity of the shows, an ideal atmosphere in which to absorb the music, the songs, and the contemporary ballads. Service was something of a musician, playing readily by ear the piano, the guitar, and the penny whistle. There is much music in his verse. Another trick that he learned from vaudeville was the mimicry of accent inspired by the Irish, Cockney, and other assorted performers and comedians who took part. He tried amateur dramatics without much success. "The world has been a stage for me and I have played the parts my imagination conceived. Rarely have I confronted reality." ${ }^{15}$ One undoubted reality was the First World War.

Service studied briefly at the University of Glasgow but he found academe relentlessly boring while the professors were dogmatic, "stuck in Victorian mud," and resistant to modern literature. He claimed to have almost come to blows with an assistant professor who awarded him a poor grade. His parting shot was "Rotten Funk you're no more than a greasy gob in a fishwife's spittle," thus unforgivably upsetting the female purveyor of fish by lowering her to the level of the academic. ${ }^{16}$

Like many Scots of his generation, he decided to emigrate. "My arrival in Canada was one of the great moments in my life and my emotions were correspondingly dynamic." ${ }^{17}$ In San Francisco, he admired the recently erected monument to Robert Louis Stevenson. "Here among strangers in a strange land was a bit of Scotland. The whaups were crying over the heather and the dew was white on the peat. This belonged to me not to the people about me."18 After many wanderings and adventures he eventually gained a position on Vancouver Island in the Victoria branch of 
the Canadian Bank of Commerce in 1904, from whence he was transferred to Kamloops and from there to Whitehorse. ${ }^{19}$

When he reached the Yukon, the trail of ninety-eight was growing cold; the glory days of the great gold rush were almost over, but there were still plenty of informants around. ${ }^{20}$ Indeed, many of the veterans of the Chilkoot Pass and the Whitehorse Rapids never left. There are still people who are hunting gold. It is to Service's credit that the style of his ballads, the use of the personal pronoun and the immediacy of the description, as well as his stated desire to become "the Spokesman of the Frozen Silence, the Avatar (manifestation) of the Great White land," ${ }^{21}$ have convinced many folk that he actually witnessed the events that he described. He did not. He collected stories from informants and, with appropriate embroidery, he turned them into rhyme. It is a little difficult to imagine that while he was writing about Dan, Lulu, and the rest he was employed as a rather sedate bank clerk. He was a recorder rather than a participant, a listener rather than a doer, and above all a self-confessed dreamer who was perfectly content to keep his readers guessing as to the extent of his own involvement in the dramas he described. We cannot now be sure whether all of his adventures happened exactly as Service described them. His autobiography was subtitled An Adventure Into Memory and clearly memory improved upon some episodes just as it wiped out others; he was undoubtedly something of a fantasist.

Service was insistent that the language of his compositions should be accessible. He mercilessly satirized literary pretension in his novel The Pretender (1915), and he emphatically agreed with his literary creation, Saxon Dane, that poetry had become too exalted, was selective of themes outside of ordinary experience, while failing as "a medium of expression ... to reach the great mass of the people." ${ }^{22}$ Service asserted that anyone with a thesaurus and a rhyming dictionary could rival his own output. That he struck a chord with his public, which has continued to sound, is indicated by the instant success that greeted Songs of a Sourdough upon its appearance in 1907. The publication went through fifteen impressions that year. ${ }^{23}$ From then on Robert Wullie never looked back. Ballads of a Cheechako appeared in 1909 while Service was still at Dawson. There too he wrote his first novel The Trail of Ninety-Eight.

Laura Berton has preserved some impressions of the man in her classic, I Married the Yukon (1954), for which Service supplied a foreword. Expecting a roisterer she encountered a quiet, solitary, non-smoking, and non-drinking man who quit the scene of a public hanging in Dawson, disgust overcoming curiosity. She describes how he would write in his 
cabin on wallpaper that he hung up, studied and modified until he was happy with the result. James Wickersham knew him as Bob Service to whom he was "introduced smilingly as a writer of poetry." ${ }^{24}$ Walter R. Hamilton asserted that Service sold copies of his autograph "under the counter," so to speak, when he worked at the bank in Dawson. He was a fan of the poet, publishing some the messages Service sent over the years to the annual Sourdough reunions in Vancouver. He actually attended their banquet in 1940. One of Hamilton's virtues is that he notes other Yukon poets, supplying some examples of the work of such people as Robert Dick, Sarah Drury Taylor, Edmund Ironside, R.P. Wilson, and "Klondike Kate" Rockwell. Whether his assertion that Service's Great War experiences did not stir his imagination "as did those of his Yukon days" is a matter of debate..$^{25}$ It could be argued that his war poems attracted a whole new readership far beyond the Yukon.

He quit the bank in 1910. After a spell in the United States, he travelled east to visit his family who had emigrated to Canada. In 1912 he left the Yukon, never to return. When the guns of August changed Europe forever, Service was in Paris, leading the life of a bohemian with his new wife. There are three main sources for Service's wartime experiences apart from Rhymes of a Red Cross Man. In Ballads of a Bohemian (1921) he adopted the unusual convention of linking his verse with passages of prose, which purport to have been written by one Stephen Moore whose experience as an ambulance man closely parallels that of his creator. Service also discusses the war in his second volume of autobiography, Harper of Heaven (1948). The first accounts of his wartime experiences occur in the searing, critical accounts of the horrors he published in a series of dispatches in the Toronto Star between 11 December 1915 and 29 January 1916. He had already tasted the bitterness of conflict, since in 1912 he had been sent by the Star as a war correspondent to the Balkans, where he served in the Red Crescent. There he discovered that war was "Hell in a special deluxe edition with cuts, steel engravings, and the autograph of Lucifer himself." The overcrowded cholera camps seemed like "a dream, a nightmare, the fantastic acting of a diabolic drama, too realistic to be real." 26

At the outbreak of war Service volunteered for the Seaforth Highlanders, but was turned down on health grounds. He became a rather unsuccessful war correspondent and was almost shot as a spy at Dunkirk. Only six war correspondents were officially recognized as such in May 1915; they were subject to a censorship as severe as the suspicion and distaste with which the military viewed them. ${ }^{27}$ Rejection by the Seaforths convinced him that he was a pacifist of a kind. "Though I did not want to kill I was willing to take the chance of being killed." ${ }^{28}$ Consequently, 
he joined the American Ambulance Unit in order to acquire first-hand knowledge of action. Although accepted on condition that he did not write about his experiences, he sent regular dispatches to the Toronto Star.

The communications for the Star undoubtedly gave a much more explicit account of the savagery and pain of battle than anything that was currently available to the English-reading public. I have long thought they should be reprinted alongside the war poems into which they directly fed.

And beyond the crosses are many open graves. They will not wait for long. Already I can hear the guns that are making for each mouth his morsel. They will soon be filled, these gaping graves. Then in years to come when the names on the crosses are blurred and worn, mothers and children will come here to weep. And perhaps it is well so. Peace, so precious, must be bought with blood and tears. These are the men who pay the price. Come let us honour them, aye, and envy them the manner of their dying for not all the jewelled orders on the breasts of the living can vie in glory with the little wooden crosses the humblest of these has won. ${ }^{29}$

Soon the worth of the cause is overwhelmed by the obscene agonies to which the combatants are exposed. A captain discusses fear (Toronto Star, 8 January 1916). Daily the ambulance man picks up "shattered wrecks of blood and bone," manoeuvring his vehicle to avoid the casualties littering the roadway - "Exquisite irony! to be wounded and then to be killed by the ambulance." Night and day the "Red Harvest" is gathered (Toronto Star, 29 January 1916). The latter article was also published by the Dawson Daily News on 7 March 1916. ${ }^{30}$ Small wonder the authorities favoured censorship.

Rhymes of a Red Cross Man begins with a forward explaining that he "tinkered at his bits of rhyme / In weary, woeful, waiting times" between ambulance trips, and in various sites around the battlefield. So far as Service was concerned the entire exercise was futile.

For through it all like horror runs The red resentment of the guns.

And you yourself would mutter when You took the things that once were men, And sped them through that zone of hate To where the dripping surgeons wait; And wonder too if in God's sight War ever, ever can be right. ${ }^{31}$ 
"The Call" begins, conventionally enough, on a note of jingoism as many "hark to the shout of war" only to face betrayal by their superiors, while their womenfolk, unusually in war verse of 1916, are not forgotten as they face a lifetime of mourning. They are urged to heed,

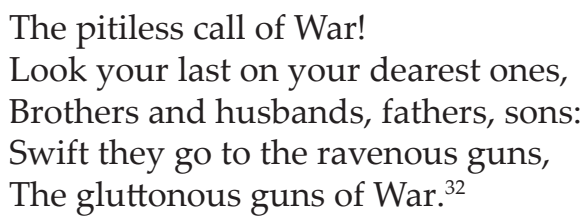

He laments the naive foolishness while ironically admiring the bravery of schoolboys who,

turn out with the rallying cry of their schools, Just bent on playing the game ...

$$
\text { ..... }
$$

Thank God! We know that he "batted well" In the last great Game of all. ${ }^{33}$

As one who honed his sporting talents on the playing fields of Hillhead Public School, Glasgow, rather than those of Eton, he is here deploring the transfer of mere boys from the playground to the cockpit of war. Although poverty-stricken, exploited, and fatalistic, working men do not want to fight, they are prepared to do so for King and Country - "Them politicians with their greasy ways / them empire-grabbers - fight for 'em? No fear!" 34 The Irish were celebrated in "The Convalescent," as were the Scots, the subject of the sentimental ditty, "The Haggis of Private McPhee."

In one of his Star dispatches, Service rejoiced that he met an individual who from Athabasca had travelled 7,000 miles $(11,265 \mathrm{~km})$ to take part in the war. "The Man from Athabaska" celebrates the Canadians in a highly evocative poem about sixty-year-old Mike, who has never turned down the chance of a scrap since he was twenty-one and who goes off to become an exhibition sniper, plugging a "Boche" at a distance of half a mile. At night his comrades gather round him.

... and I tell them of my roaming

In the Country of the Crepuscule beside the Frozen Sea.

Where the musk-ox runs unchallenged, and the cariboo goes homing;

And they sit like little children, just as quiet as can be;

Men of every crime and colour, how they harken unto me! 
And I tell them of the Furland, of the tumpline and the paddle,

Of secret rivers loitering, that no one will explore;

And I tell them of the ranges, of the pack-strap and the saddle,

And they fill their pipes in silence, and their eyes beseech for more;

While above the star-shells fizzle and the high explosives

roar.

And I tell of lakes fish-haunted, where the big bull moose are calling,

And forests still as sepulchres with never trail or track;

And valleys packed with purple gloom, and mountain peaks appalling,

And I tell them of my cabin on the shore of Fond du Lac;

And I find myself a-thinking: Sure I wish that I was back. ${ }^{35}$

It is a great pity that Service never picked up his pen to versify the life of Joe Boyle, the Yukon's true war hero!

As he had shown in the Yukon poems, Service remained fascinated by the obsessions and attitudes of individuals in extreme situations. In "The Odyssey of "Erbert 'Iggins" he reveals one of the saddest experiences of the combatants. Erbert with a mate goes to the assistance of a wounded German who promptly shoots his friend.

Now what would you do? I arst you.

There was me slaughtered mate.

There was that 'Un

(I'd collered 'is gun),

A-snarlin' 'is 'ymn of 'ate.

Wot did I do? 'Ere, whisper...

'E'd a shiny bald top to 'is 'ead,

But when I got through,

Between me and you,

It was 'orrid and jaggy and red..$^{36}$

It was, and is, a commonplace of war propaganda to dehumanize the enemy, but in this neatly contrived passage, Erbert proves himself as guilty as his victim, equally susceptible to moral corruption.

"Fleurette" describes the utter despair of a Canadian missing a leg and a face. He believes he looks like a gargoyle but he is rescued from total 
despair by a kiss from the beautiful Fleurette. ${ }^{37}$ Another poem, this one inspired by an earlier incident described in his Star column, was "Funk," or cowardice. He has a searing and near-repellant rhyme spoken by a soldier impaled upon barbed wire and who prays for a bullet to relieve his agony.

O God, take the sun from the sky!

It's burning me, scorching me up.

God, can't you hear my cry?

Water! A poor little cup!

It's laughing the cursed sun!

See how it swells and swells

Fierce as a hundred hells!

God, will it never have done?

It's searing the flesh on my bones;

It's beating with hammers red

My eyeballs into my head;

It's parching my very moans.

See! It's the size of the sky,

And the sky is a torrent of fire,

Foaming on me as I lie

Here on the wire ... the wire...$^{38}$

He writes of tough soldiers faintly embarrassed to be caught laying flowers on a dead comrade's grave. ${ }^{39}$ He recounts individual acts of heroism the more heroic because no one is present to observe the action of the hero. He describes his own direct experience in "The StretcherBearer." He confronts the stunned awareness of men who see themselves in the broken bodies of the dying enemy.

Oh, it isn't cheerful to see a man, the marvellous work of God,

Crushed in the mutilation mill, crushed to a smeary clod;

Oh, it isn't cheerful to hear him moan; but it isn't that 1 mind,

It isn't the anguish that goes with him, it's the anguish he leaves behind.

For his going opens a tragic door that gives on a world of pain,

And the death he dies, those who live and love, will die again and again. ${ }^{40}$ 
He may have been one of the first-if not the first-of the war poets to speculate on the alienation of the warrior once he had returned to civilian life, as in "The Revelation."

The same old sprint in the morning, boys, to the same old din and smut;

Chained all day to the same old desk, down in the same old rut:

Posting the same old greasy books, catching the same old train:

Oh, how will I manage to stick it all, if ever I get back again?

"Afternoon Tea" is as devastating as it is dramatically effective:

...my man was descending before me, when sudden a cry! a shot!

(I say, this cake is delicious. You make it yourself, do you not?)

My man? Oh, they killed the poor devil ...

And now by Jove! How I've bored you. You've just let me babble away;

Let's talk of the things that matter-your car or the newest play.... ${ }^{41}$

Rhymes was dedicated to Service's brother Albert, killed in action in August 1916, and it became an instant bestseller. Many of the images that he conjured have since become clichés through literature and movies, but what is to be understood is that Robert Service was very probably the first to poetically place those images before the public. His concern with the plight of the individual soldier was highly unusual, possibly even unique, at this stage of the conflict. In much First War poetry the poet does not doubt the value of the cause as, for example, in Rupert Brooke's famous effusion, "The Soldier," or in what became the best-known poem of the war, Scots Canadian John McCrae's "In Flanders Fields," which was used to raise money for war bonds.

Take up our quarrel with the foe:

To you from failing hands we throw

The torch; be yours to hold it high.

If ye break faith with us who die

We shall not sleep, though poppies grow

In Flanders fields. ${ }^{42}$ 
It is generally agreed that the first major public disenchantment with the war set in after the Battle of the Somme, July to November 1916. ${ }^{43}$ Before the battle, the poetic fraternity-Brooke, McCrae, Julian Grenfell, and the young Wilfrid Owen - wrote with a certain innocence swathed in patriotic sentiment; war to them was a noble, lofty enterprise. The Somme changed minds and attitudes. The British and their allies lost 420,000, the French 194,000. Three Commonwealth soldiers were lost for every two Germans. It may now be suggested that Robert Service not only helped foster the widespread sense of disillusionment, but that he was among the first to publish the stark reality of the wartime experience from the point of view of the non-commissioned combatant. ${ }^{44}$ It is worth recalling that virtually all of the war poets were from privileged backgrounds or were commissioned as officers, or were both. Service was neither.

The chronology of Rhymes is important. Conscription had been introduced in Britain in January 1916; the soldiers were no longer volunteers singing "Tipperary" as they marched to oblivion. Service became ill during the spring of 1916 and he was invalided out. While convalescing, he decided to compose poems based upon his recent experience, and in five months he produced sixty pieces. He clearly began to write before the battle. His collection was published in the fall of 1916 and topped the bestseller lists for nine months, his success directly reflecting the public mood following the Somme as jingoism and patriotism gave way to fear and despair. The publication can have done little to enhance the war effort. In fact it could have been regarded in certain quarters as treason; men on the front lines were shot for less.

A considerable amount of war poetry was reaching print by early 1917. Reviews give some indication of how Service was received. One opined that Rhymes did not quite capture "the ultimate tragedy and mystery, the agony and wild humour and fearful rapture of war," but that it did communicate popular versions of all of those things, "versions which tell about them convincingly and pass current," though their author was compared unfavorably with Julian Grenfell. Another, reviewing half a dozen books of war poetry including Service, was moved to comment on the "spiritual bankruptcy of the age." Both critics sought comfort that the poets were unable to communicate, the second seeking a "renewal of faith, [a] glimpse of light above the smoke of battle," the other hoping to detect "the very heart-cry of emotion." Both also favoured dead poets who represented the patriotic ethos and the essential nobility of sacrifice. ${ }^{45}$ What the reviews clearly demonstrate is a split in receptivity between those performing in the theatre of war and their domestic audience, 
between literary sensibility and experiential verse, perhaps between elite and popular perceptions. In war poetry, civilians and soldiers seem to write about different aspects, the folks at home clinging to ideas about valour and sacrifice and country while the battle-weary were beginning to say things that not everyone at home wanted to hear. There was no "glimpse of light" in Service because there was none to see, except perhaps the phantom glimmer of a future world totally free of war. About war he was totally pessimistic; it had no redeeming features.

There is a debate to be had about Service's wisdom in publishing these poems. There is no biographical information in Rhymes of a RedCross Man, except a bare mention of his earlier collections, Sourdough, Cheechako, and Rolling Stone, on the title page. Those who bought expecting more Yukon capers were doomed to disappointment while those who purchased on impulse, without having heard of him, might have been outraged and disgusted in equal measure. It is small wonder that the military and the political establishment had little love for his verse. In the final analysis, his stance seems highly courageous. The publication could have ruined his literary career. On the other hand, many were perhaps grateful that he was communicating some of the savage reality of war rather than governmental propaganda.

Not all of the ballads in Rhymes were relentlessly grim. There were still echoes of the Yukon humour in pieces such as "Soulful Sam" or "The Whistle of Sandy McGraw." More serious was Service's awareness that war did not exclusively concern men; women are central to the first poem and the last of the Red Cross sequence. The final moving and compassionate poem is dedicated to the women who face survival alone as the poet looks into "the aching womb of night."

I look into the aching womb of night;

I look across the mist that masks the dead;

The moon is tired and gives but little light,

The stars have gone to bed.

The earth is sick and seems to breathe with pain;

A lost wind whimpers in a mangled tree;

I do not see the foul, corpse-cluttered plain,

The dead I do not see.

The slain I would not see ... and so I lift

My eyes from out the shambles where they lie;

When lo! a million woman-faces drift

Like pale leaves through the sky. 
The cheeks of some are channelled deep with tears;

But some are tearless, with wild eyes that stare

Into the shadow of the coming years

Of fathomless despair.

And some are young and some are very old;

And some are rich, some poor beyond belief;

Yet all are strangely like, set in the mould

Of everlasting grief.

They fill the vast of Heaven, face on face;

And then I see one weeping with the rest,

Whose eyes beseech me for a moment's space....

Oh eyes I love the best! ${ }^{46}$

Fifty-one poems were published in Rhymes. Another ten, which for one reason or another were excluded in 1916, appeared in the first three sections of Book Four of Ballads of a Bohemian. The remaining five war poems in the volume, including the lengthy "Les Grands Mutiles," read as if they had been written after the Armistice. "Ballads" is really Service's valediction to the age of innocence as freedom had to be surrendered to the criminal folly of war.

One of the most memorable lines Service penned appears in the Rhymes poem "My Mate" - 'E was killed so awful sudden that 'e 'adn't time to die"; another in the same poem is:

There's some as fights for freedom and there's some as fights for fun,

But me, my lad, I fights for bleedin' 'ate. ${ }^{47}$

A further striking line, this one from "The Red Retreat," is "all our hands was blistered, for our rifles was so hot." 48 Another poem articulates the bitterness of the fighting man - "If them as made it "ad to fight, there wouldn't be no war." 49 "Carry On" discusses the challenge of continuing to battle against overwhelming odds:

It's easy to fight when everything's right,

And you're mad with the thrill and the glory;

It's easy to cheer when victory's near,

And wallow in fields that are gory.

It's a different song when everything's wrong,

When you're feeling infernally mortal;

When it's ten against one, and hope there is none,

Buck up, little soldier, and chortle. ${ }^{50}$ 
"Pilgrims" anticipates the dark tourism that will follow the war when relatives make summer trips to visit the graves of their fallen. ${ }^{51}$

The dying continues in the "Ballads of a Bohemian" and we may suspect that some of these poems were held over as a result of self-censorship. The horror of "The Blood-Red Fourragére" is utterly relentless.$^{52}$ Even Service must have realized that there were some subjects that his public just could not take.

What was the blackest sight to me

Of all that campaign?

A naked woman tied to a tree

With jagged holes where her breasts should be,

Rotting there in the rain. ${ }^{53}$

In this poem the French colonel has his troops march past the tree in order to instill a hatred of the enemy into their souls. Equally horrible is "The Three Tommies," which details the deaths of a painter, a musician, and a writer; one verse will make the point:

Oh, Harley and Fanning and Barret, they were bloody good friends o' mine;

Their bodies are empty bottles; Death has guzzled the wine; What's left of them's filth and corruption .... Where is the Fire Divine? ${ }^{54}$

"Les Grands Mutiles" describes a trilogy - The Sightless Man, The Legless Man, and The Faceless Man. The legless victim laments that soon no one will remember when, how or why he lost his limbs. But all is not lost-he is a shoemaker, "Good luck one has no need of legs / To make a pair of shoes." ${ }^{55}$ Bathos and crass sentimentality combine in this composition to deter modern readers, but such overkill is very reminiscent of the folk tradition, which seldom hesitates to overstate the obvious. Nonetheless, if the poem was in existence in 1916, it was hardly something that Service's audience could be expected to digest during the Christmas holidays. In "The Wife," Annie's husband is killed having promised to be home for the festive season: 
A victory .... Ah what care I?

A thousand victories are vain,

Here in my ruined house I cry

From out my black despair and pain,

I'd rather, rather damned defeat,

And have my man with me again

........................

What matters it to us poor folk?

Who win or lose, it's we who pay,

Oh, I would laugh beneath the yoke

If I had him at home to-day;

One's home before one's country comes:

Aye, so a million women say.

As it happens, Annie's husband shows up in the last verse but not before she (and Service) have made their point. ${ }^{56}$

In the First World War, Service confronted his own reality, perhaps for the only time in his life.

It's coming soon and soon, mother, it's nearer every day.

When only men who work and sweat will have a word to say;

When all who earn their honest bread in every land and soil

Will claim the Brotherhood of Man, the Comradeship of Toil;

When we, the Workers, all demand: 'What are we fighting for?' ...

Then, then we'll end that stupid crime, that devil's madness - War. ${ }^{57}$

When the United States entered the war, the Ambulance Unit was disbanded and Service obtained a very comfortable job reporting the activities of the Canadian Expeditionary Force complete with guide, chauffeur, and the rest. After the war, he returned to Paris. He had many more adventures. He visited Russia twice, leaving the second time just as the Germans invaded Poland. He was death-listed for his unflattering published remarks about "Huns," but he left France just ahead of the invaders, who used his Breton summer home as a command post. During the latter part of his life, he lived quietly at Monte Carlo and at Dream Haven, Brittany. This likeable, caring, somewhat egocentric, and slightly loveless man died peacefully in 1958. He furnished his own envoi-“The 
measure of our sunshine is the brightness we can kindle in the eyes of others." ${ }^{58}$

At the end of the war, Service had been compiling a text to be called War Winners in which he attempted to encapsulate the whole futile experience. He was making excellent progress when Armistice was declared. Service joined in the dancing, cheering, singing, hugging, and kissing on the frenzied streets of Paris. In the midst of the jollification he suddenly thought of all who had given their lives and rushed home to tear up his manuscript.

"That ends it" I said. "No more war. Not in my lifetime.

Curse the memory of it. Now I will rest and forget." ${ }^{59}$

It is noteworthy that although Service continued throughout his life to write about and communicate with the Yukon and Yukoners whom he described as "among the greatest friends of my life," he never did return to the subject of the First World War. Unfortunately, like so many of his generation, he was to live through a period of ever-threatening and everpresent war and, of course between 1939 and 1945 a second world war, which he viewed from afar. He spent the war years in British Columbia and California. ${ }^{60}$ In Hollywood he had a bit part in The Spoilers, a film about the gold rush, now transposed from the Yukon to Alaska. It starred Marlene Dietrich, John Wayne, and Randolph Scott, inspiring the dire verse:

Johnny Wayne and Randy Scott

They fought and fought and fought and fought

With joy they shed each other's gore,

And then they paused and shed some more.

He wrote a couple of poems that alluded to the Spanish Civil War and produced a few on the Second World War. The "Volunteer" sings as he goes off to war, taking comfort in the notion that "in wars not one in ten / Are killed of fighting men" only to meet a predictable fate: "No kiss for him beneath the sun: / From ten Death chose the ONE." ${ }^{61}$ The "European Conscript" claims he is not a patriot worth a damn; in fact he detests his country:

The swine who rule us claim they have the right

To take our lives and use them at their need;

To force us for invested funds to fight,

To sacrifice us to imperial greed:

In name of nationality to bleed. ${ }^{62}$ 
Service wonders whether a French military marshal, now in his dotage, who could once send 10,000 men to their deaths, had any regrets and suggests he was not alone to blame; all were complicit in war. In Songs For My Supper he reflected on the conflict:

Go forth with rage of race and slay;

Pile up the corpses for

What's murder called in Peace-always

Is hallowed in War. ${ }^{63}$

Poor poetry but a sound observation. In "The Mighty Atom" he recalled that a ton of bombs caused great devastation during the First World War, while in the Second World War a thousand bombs each weighing a ton might be unleashed.

Today I read: "A suitcase small

Can hold a bomb that will destroy

A mighty city, shambling all." -

The knowledge does not make for joy;

London, New York and Moscow might

Be cinders in a single night. ${ }^{64}$

When the sunshine was blocked out for Service in the 1914-1918 war, he produced his greatest work. He was not, nor did he aspire to be, a great poet but he kindled brightness in others by talking to them in their own language, free of pretension. He belonged to an older world of the ballad and the broadside, exploiting the rhythms and conventions of that world to record and articulate the feelings of ordinary women and men caught up in the greatest disaster they had known, "the maximum event in all human history," as one informant put it. ${ }^{65}$ With governments intent upon orchestrating jingoism, he was not popular, yet he struck a chord that sounded in the souls of the war generation as early as 1916. His was not the poetry of King, Country, and Empire; it was the voice of the victims, the mangled, and the manipulated. His verse cannot stand comparison with that of the privileged war poets, yet he anticipated many of the metaphors, images, and sentiments for which they are now lauded. Criticism has failed Service because of his style and his success, perhaps also, because of his lowly social status; marginalized by the critics, he remained at the forefront of popular literature. 
It was impossible to forget the First War since the guns echoed throughout his life. In any case he did not intend to forget. The unforgettable unforgotten remained to haunt him as his own rhymes remained to haunt posterity. The long hard road from Scotland and the Yukon to the trenches of France taught him that true victory would not be gained through defeat of the enemy, but rather, as he wrote in Rhymes of a Red Cross Man,

If by the victory all we mean is a broken and brooding foe;

Is the pomp and power of a glitt'ring hour, and truce for an age or so:

By the clay-cold hand on the broken blade we have smitten a bootless blow!

If this be all: by the blood-drenched plains, by the havoc of fire and fear,

By the rending roar of the War of Wars, by the Dead so doubly dear....

Then our Victory is a vast defeat, and it mocks us as we cheer.

When our children's children shall talk of War as a madness that may not be;

When we thank our God for our grief to-day, and blazon from sea to sea

In the name of the Dead the banner of Peace ... that will be Victory. ${ }^{66}$

No poet who sold so many books said so much in 1916. To Robert Service, bard of the Yukon and of the people, credit is long overdue.

\section{Author}

Edward (Ted) J. Cowan is emeritus professor of Scottish history and literature at the University of Glasgow in Scotland.

\section{Notes}

1. Melody Webb, Yukon: The Last Frontier (Lincoln Nebraska, 1993), 30.

2. Clifford Wilson, Campbell of the Yukon (Toronto, 1970), passim.

3. "Murray, Alexander Hunter," Dictionary of Canadian Biography, http://www. biographi.ca/en/bio/murray_alexander_hunter_10E.html

4. Robert E. Johnson, Sir John Richardson Arctic Explorer, Natural Historian, Naval Surgeon (London, 1976), passim. 
5. Michael Gates and Blair Neatby, Yukon's War Dead 1914-1918, Yukon Archives, 2016.

6. Robert W. Service, The Trail of Ninety-Eight A Northland Romance (New York, 1911), 117.

7. Service, Trail of Ninety-Eight, 445-446.

8. Collected Poems of Robert Service (1907, New York, 1940), 535.

9. This article is intended to build upon, expand, and correct my earlier contribution, "The War Rhymes of Robert Service, Folk Poet," Studies in Scottish Literature, Vol. 24, Issue 1: 12-27. I had no notion of returning to the subject until I was invited to participate in The North and the First World War Conference, held in Whitehorse, Yukon, May 2016. The entire experience was highly memorable, but I felt particularly honoured to be asked to read some of Service's work at his cabin in Dawson City. However, some overlap with the earlier publication is inevitable and happily admitted.

10. Stanley Atherton, "The Klondike Muse," Canadian Literature 47 (1971): 67.

11. Robert Service, Ploughman of the Moon: An Adventure into Memory (New York, 1945) 83-84.

12. At least two critics have drawn attention to the folk nature of Service's output-Martin Bucio, "Folk Poetry of Robert W. Service," Alaska Review 2 (Fall 1965): 16-26; and Edward Hirsh "A Structural Analysis of Robert Service's Yukon Ballads," Southern Folklore Quarterly 40 (1976): 125-140.

13. Service, Ploughman, 15.

14. William D. Mathieson, My Grandfather's War: Canadians Remember the First World War 1914-18 (Toronto, 1981), 7.

15. Service, Ploughman, 101.

16. Service, Ploughman, 98-100.

17. Service, Ploughman, 141.

18. Service, Ploughman, 191. The reference here is to the Galloway novelist, S.R. Crockett, with whom Robert Louis Stevenson corresponded. For his friend, RLS wrote his beautiful poem To S.R.Crockett:

"Blows the wind to-day, and the sun and the rain are flying;

Blows the wind on the moors today and now,

Where about the graves of the martyrs the whaups are crying-

My heart remembers how!"

S. R. Crockett, The Stickit Minister's Wooing and other Galloway Stories,

(London, 1890), xi-xii.

19. On his adventures in Canada and America, see Ploughman, 139-304. Useful studies of Service's biography and output include Carl F. Clinck, Robert Service: A Biography (Toronto, 1976); G.W. Lockhart, On the Trail of Robert Service (Barr, Ayrshire, 1991); James Mackay, Robert Service Vagabond of Verse: A Biography (Edinburgh, 1995); and Enid Mallory, Robert Service: Under the Spell of the Yukon (2006; Surrey BC, 2008). See also Peter J. Mitham, Robert W. Service: A Bibliography (New Castle, Delaware, 2000). 
20. I was mistaken to state previously that the Trail of ' 98 was long since cold. There were clearly still numerous veterans around during Service's time in the Yukon and indeed some of them never left.

21. Service, Trail of Ninety-Eight, 211.

22. Collected Poems, 466.

23. Klinck, Robert Service. A Biography, 39.

24. James Wickersham, Old Yukon: Tales, Trails, and Trials (Washington DC, 1938), 30.

25. W.R. Hamilton, The Yukon Story (Vancouver, 1964) 204-213, 224-225.

26. His article was reprinted in the Toronto Star, 5 Apr 1992. It was originally published on 1 Feb 1913, dated from Constantinople in Jan 1913. According to Klinck, Biography, 74, Service spent Christmas 1912 at Budapest on his return from Constantinople en route to Paris.

27. A.J.P. Taylor, English History 1914-45 (Oxford, 1965), 18.

28. Robert Service, Harper of Heaven: A Record of Radiant Living (New York, 1948), 78.

29. Toronto Star, 18 Dec 1915, the second article of the series.

30. I am indebted to Michael Gates of Whitehorse, a prominent historian of the Yukon, for kindly providing me with a copy of Service's Dawson Daily News article.

31. "Rhymes of a Red Cross Man," Collected Poems, 292.

32. "The Call," Collected Poems, 294.

33. "The Fool," Collected Poems, 195-196.

34. "The Volunteer," Collected Poems, 297.

35. "The Man from Athabasca," Collected Poems, 300-302.

36. "The Odyssey of 'Erbert 'Iggins," Collected Poems, 311-312.

37. "Fleurette," Collected Poems, 320-323.

38. "On the Wire," Collected Poems, 336.

39. "Bill's Grave," Collected Poems, 339.

40. "Only a Boche," Collected Poems, 361.

41. "Afternoon Tea," Collected Poems, 412-414.

42. John McCrae, born in Guelph, Ontario, was the grandson of a Scottish emigrant from Carsphairn, Galloway. See John F. Prescott, In Flanders Fields: The Story of John McCrae (Erin, 1985).

43. Modris Eksteins, Rites of Spring: The Great War and the Birth of the Modem Age (Toronto, 1989) 144-145; John Lehmann, The English Poets of the First World War (London, 1982), 8.

44. Mrs. Cleghorn of Guelph relates that when her husband returned from the Front in 1916, he presented her with a copy of Rhymes of a Red Cross Man. "This," he said, "will give you the clearest idea of what things are like over there." "The best part of the story" says Mrs. Cleghorn, "is that I am a full cousin of John McCrae!" 
45. Harriet Monroe, "War Poems," Poetry 10 (Aug. 1917): 271-278; Florence Finch Kelly, "The Poets Enlist under Mars," Bookman 44 (Jan. 1917): 510 513. The essay also reviewed Alan Seeger's poems, without, oddly enough, mentioning one of the best-known poems to come out of the First World War, his "I have a Rendezvous with Death."

46. "The Mourners," Collected Poems, 415.

47. "My Mate," Collected Poems, 329.

48. " "The Red Retreat," Collected Poems, 304.

49. A A Song of the Sandbags," Collected Poems, 334.

50. "Carry On," Collected Poems, 351.

51. "Pilgrims," Collected Poems, 161.

52. A French military honour awarded to a military unit, in the form of a braided cord worn round the left shoulder.

53. "The Blood-Red Fourragére," Collected Poems, 554.

54. "The Three Tommies," Collected Poems, 563.

55. "Les Grands Mutiles," Collected Poems, 588.

56. "The Wife," Collected Poems, 578.

57. "Michael," Collected Poems, 577.

58. Service, Harper, 452; for details of Service's later life see Klinck, Biography and Mackay, Vagabond of Verse; Enid Mallory, Robert Service Under the Spell of the Yukon is particularly moving and perceptive.

59. Service, Harper, 94.

60. Mackay, Vagabond, 339-367.

61. Robert Service, More Collected Verse (New York, 1956); Rhymes of a Rebel, 6.

62. Rhymes of a Rebel, 8-10.

63. "Raw Recruit," More Collected Verse, Rhymes For Resentment, 12.

64. Service, More Collected Verse. Rhymes For Resentment, 13.

65. Mathieson, Grandfather's War, 13.

66. "The Song of the Pacifist," Collected Poems, 405-406. 